\title{
The Most Highly Cited Publications on Basketball Originate From English-Speaking Countries, Are Published After 2000, Are Focused on Medicine- Related Topics, and Are Level III Evidence
}

\author{
Zachary D. Griffin, B.S., Jordan R. Pollock, B.S., M. Lane Moore, B.S., \\ Kade S. McQuivey, M.D., Jaymeson R. Arthur, M.D., and Anikar Chhabra, M.D.
}

Purpose: To identify the 50 most highly cited research publications in the sport of basketball. Methods: Using the Clarivate Analytics Web of Knowledge database and the search term "basketball", we identified 2,704 articles. These articles were filtered by the total number of citations and the top 50 most cited articles with a central focus on basketball were selected for this analysis. For each article, we further identified and analyzed author name, publication year, country of origin, journal name, article type, main research topic area, competitive level, gender of study population, and the level of evidence. Results: Medicine-related topics, particularly those involving knee injuries, are more common than nonmedical topics (coaching, sports psychology etc.) among the highest cited articles. Articles originated from 13 different countries, with $48 \%$ originating in the United States. Only four authors had more than one article included in the top 50 most cited articles. Conclusion: A majority of the top 50 research articles were from English-speaking countries, published after 2000, primarily focused on medicine-related topics, and were Level III evidence. Publications examining knee injuries were the most highly cited and appear to be of high interest to current investigators. The prestige of an author's name appeared to be less influential to the number of citations. Clinical Relevance: The top 50 most cited articles list will provide researchers, medical students, residents, and fellows with a foundational list of the most important and influential academic contributions to the basketball literature.

\section{Introduction}

B asketball was invented in 1891 by Dr. James Naismith. ${ }^{1}$ Since then, it has slowly spread throughout the world. The International Basketball Federation estimates that there are currently 450 million players and fans of basketball worldwide. ${ }^{2}$ In

From the University of Texas Health Long School of Medicine, San Antonio, Texas, U.S.A. (Z.D.G.); Mayo Clinic Alix School of Medicine, Mayo Clinic, Scottsdale, Arizona, U.S.A. (J.R.P., M.L.M.); and Department of Orthopedic Surgery, Mayo Clinic, Phoenix, Arizona, U.S.A. (K.S.M., J.R.A., A.C.).

The authors report the following potential conflicts of interest or sources of funding: A.C. reports receiving grants from Stryker and personal fees from Arthrex, Zimmer-Biomet, and Thrice Medical. Full ICMJE author disclosure forms are available for this article online, as supplementary material.

Received October 7, 2021; accepted December 31, 2021.

Address correspondence to Anikar Chhabra, M.D., Department of Orthopedic Surgery, Mayo Clinic Arizona, 5777 E. Mayo Blvd., Phoenix, AZ, 85054,U.S.A.E-mail: chhabra.anikar@mayo.edu

(C) 2022 THE AUTHORS. Published by Elsevier Inc. on behalf of the Arthroscopy Association of North America. This is an open access article under the CC BY-NC-ND license (http://creativecommons.org/licenses/by-nc-nd/4.0/). 2666-061X/211419

https://doi.org/10.1016/j.asmr.2021.12.020 the United States, nearly $40 \%$ of children between the ages of 6 and 14 play basketball. 11 million youth between the ages of 12 and 17 participate in the sport, including the 1 million high school students who play for school-sponsored teams. ${ }^{3,4}$ While basketball provides many benefits to those who participate in it, injuries are common. Yearly, basketball-related injuries result in roughly 340,000 emergency department visits for youth under the age of $24 .^{5}$ These injuries often occur in game competition rather than in practice and most commonly effect the lower extremeties. ${ }^{6}$

With such a wide influence, basketball has long been a focus of research in the scientific community. Topics of basketball research have included injury prevalence and prevention, player physiology, 7,8 biomechanics, ${ }^{9,10}$ training methods to optimize development, ${ }^{11-13}$ and the characteristics of winning teams. ${ }^{14,15}$ With such a wide scope, the literature on basketball is growing rapidly, and it is nearly impossible to stay up to date on recent publications. Bibliometric analyses provide a helpful way of condensing the ever-growing available research. 
Aglioti SM, Cesari P, Romani M, Urgesi C. Action anticipation and motor resonance in elite basketball players. Nat Neurosci 2008;11:1109-1116. Plisky PJ, Rauh MJ, Kaminski TW, Underwood FB. Star excursion balance test as a predictor of lower extremity injury in high school basketball players. J Orthop Sports Phys Ther 2006;36:911-919.

Krosshaug T, Nakamae A, Boden BP, et al. Mechanisms of anterior cruciate ligament injury in basketball: Video analysis of 39 cases. Am J Sports Med 2007;35:359-367. review. Am J Sports Med 2005;33:524-530.

7 Koga H, Nakamae A, Shima Y, et al. Mechanisms for noncontact anterior cruciate ligament injuries: Knee joint kinematics in 10 injury situations from female team handball and basketball. Am J Sports Med. 2010;38:2218-2225.

Abdelkrim NB, Fazaa SE, Ati JE. Time-motion analysis and physiological data of elite under-19-year-old basketball players during competition. Brit J Sports Med 2007;41:69-75.

9 McKay GD, Goldie PA, Payne WR, Oakes BW. Ankle injuries in basketball: Injury rate and risk factors. Brit J Sports Med 2001;35:103-108.

McGuine T, Greene J, Best T, Leverson G. Balance as a predictor of ankle injuries in high school basketball players. Clin J Sport Med 2000;10:239244.

McInnes SE, Carlson JS, Jones CJ, McKenna MJ. The physiological load imposed on basketball players during competition. J Sports Sci 1995;13:387-397.

Rozzi SL, Lephart SM, Gear WS, Fu FH. Knee joint laxity and neuromuscular characteristics of male and female soccer and basketball players. Am J Sports Med 1999;27:312-319.

13 Dirks KT. Trust in leadership and team performance: Evidence from NCAA basketball. J Appl Psychol 2000;85:1004-1012.

Mah CD, Mah KE, Kezirian EJ, Dement WC. The effects of sleep extension on the athletic performance of collegiate basketball players. Sleep 2011;34:943-950.

Bressel E, Yonker JC, Kras J, Heath EM. Comparison of static and dynamic balance in female collegiate soccer, basketball, and gymnastics athletes. J Athl Train 2007;42:42-46.

Montgomery PG, Pyne DB,

:75-86.

Messina DF, Farney WC, DeLee JC. The incidence of injury in Texas high school basketball. Am J Sports Med 1999;27:294-299.

Kujala UM, Taimela S, Antti-Poika I, Orava S, Tuominen R, Myllynen P. Acute injuries in soccer, ice hockey, volleyball, basketball, judo, and karate: analysis of national registry data. BMJ 1995;311:1465-1468.

Zelisko JA, Noble HB, Porter M. A comparison of men's and women's professional basketball injuries. Am J Sports Med 1982;10:297-299.

Ziv G, Lidor R. Physical attributes, physiological characteristics, on-court performances and nutritional strategies of female and male basketball players. Sports Med 2009;39:547-568.

21 Gray J, Taunton JE, McKenzie DC, Clement DB, McConkey JP, Davidson RG. A survey of injuries to the anterior cruciate ligament of the knee in female basketball players. Int J Sports Med 1985;6:314-316.

22 Abdelkrim NB, Castagna C, Jabri I, Battikh T, El Fazaa S, El Ati J. Activity profile and physiological requirements of junior elite basketball players in relation to aerobic-anaerobic fitness. J Strength Cond Res 2010;24:2330-2342.

23 Ostojic SM, Mazic S, Dikic N. Profiling in basketball: Physical and physiological characteristics of elite players. J Strength Cond Res 2006;20:740744.

LaBella CR, Huxford MR, Grissom J, Kim K-Y, Peng J, Christoffel KK. Effect of neuromuscular warm-up on injuries in female soccer and basketball athletes in urban public high schools: Cluster randomized controlled trial. Arch Pediatr Adolesc Med 201 1;165:1033-1040. randomized controlled trial. Clin J Sport Med 2007;17:17-24. 
study at West Point. Am J Sports Med 1994;22:454-461

Wilson MR, Vine SJ, Wood G. The influence of anxiety on visual attentional control in basketball free throw shooting. J Sport Exer Psychol 2009;31:152-168.

Borowski LA, Yard EE, Fields SK, Comstock RD. The epidemiology of US high school basketball injuries, 2005-2007. Am J Sports Med 2008; $36: 2328-2335$

Narazaki K, Berg K, Stergiou N, Chen B. Physiological demands of competitive basketball. Scand J Med Sci Sports 2009;19:425-432.

Matavulj D, Kukolj M, Ugarkovic D, Tihanyi J, Jaric S. Effects of plyometric training on jumping performance in junior basketball players. J Sports Med Phys Fitness 2001;41:159-164.

Leppanen, M; Pasanen, K; Kujala, UM, et al. Stiff landings are associated with increased ACL injury risk in young female basketball and floorball players. Am J Sports Med 2017;45:386-393.

Simenz CJ, Dugan CA, Ebben WP.
Strength Cond Res 2005;19:495.

Bourbousson J, Sève C, McGarry T. Space-time coordination dynamics in basketball: Part 2. The interaction between the two teams. J Sports Sci 2010;28:349-358.

Nemhauser GL, Trick MA. Scheduling a major college basketball conference. Oper Res 1998;46:1-8.

Mihata LCS, Beutler AI, Boden BP. Comparing the incidence of anterior cruciate ligament injury in collegiate lacrosse, soccer, and basketball players: Implications for anterior cruciate ligament mechanism and prevention. Am J Sports Med 2006;34:899-904.

Labella CR, Smith BW, Sigurdsson A. Effect of mouthguards on dental injuries and concussions in college basketball. Med Sci Sports Exer 2002;34:41-44.

Hoare DG. Predicting success in junior elite basketball players-the contribution of anthropometic and physiological attributes. J Sci Med Sport 2000;3:391-405.

Stojanovic, E; Stojiljkovic, N; Scanlan, AT; Dalbo, VJ; Berkelmans, DM; The activity demands and physiological responses encountered during basketball match-play: A systematic review. Sports Med 2018;48:111-135.

Dick R, Hertel J, Agel J, Grossman J, Marshall SW. Descriptive epidemiology of collegiate men's basketball injuries: National Collegiate Athletic Association Injury Surveillance System, 1988-1989 through 2003-2004. J Athl Train 2007;42:194-201.

Matthew D, Delextrat A. Heart rate, blood lactate concentration, and time-motion analysis of female basketball players during competition. $J$ Sports Sci 2009;27:813-821.

Spiteri, T, Nimphius, S, Hart, NH, Specos, C, Sheppard, JM, Newton, RU. Contribution of strength characteristics to change of direction and agility performance in female basketball athletes. J Strength Condit Res 2014;28:2415-2423.

Cook JL, Khan KM, Kiss ZS, Griffiths L. Patellar tendinopathy in junior basketball players: A controlled clinical and ultrasonographic study of 268 patellar tendons in players aged 14-18 years. Scand J Med Sci Sports 2000;10:216-220.

47 Longo UG, Loppini M, Berton A, Marinozzi A, Maffulli N, Denaro V. The FIFA 11+ Program is effective in preventing injuries in elite male basketball players: A cluster randomized controlled trial. Am J Sports Med 2012;40:996-1005. 


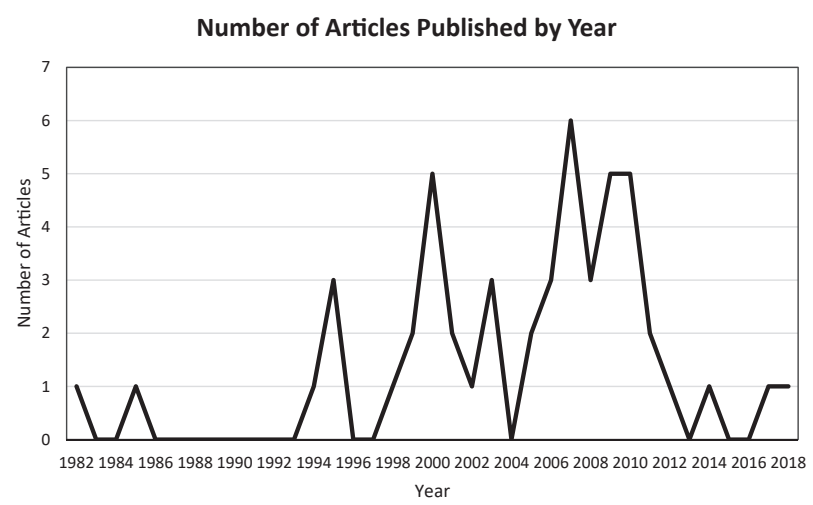

Fig 1. Number of articles published by year. Top 50 most cited basketball articles published by year.

Bibliometric citation analyses provide a quantitative method of investigating the impact of scientific articles by analyzing the number of citations. Articles with a high number of citations are often considered the most influential articles in a particular field. ${ }^{16}$ Researchers use citation analyses to identify which subtopics are of most interest to fellow investigators, to learn from highyield articles in an unfamiliar field, and to help students and novice researchers gain foundational knowledge about a topic. These analyses have been widely used in medicine. ${ }^{17-30}$ Similar analyses have been performed in the fields of ecology, ${ }^{31}$ biotechnology, ${ }^{32,33}$ medical education, ${ }^{34}$ soccer, ${ }^{35}$ and various others. ${ }^{36-39}$ The purpose of this study was to identify the 50 most highly cited research publications in the sport of basketball. The hypothesis of this study was that articles with medicine-related topics would be highly cited.

\section{Methods}

Given the public nature of these data, institutional review board approval was deemed exempt by our institutional review board. As described in similar studies conducting bibliometric analyses of orthopedic literature, the Clarivate Analytics Web of Knowledge database was used to gather data and metrics. ${ }^{40-47}$ The database was queried on December 14, 2021. All articles containing the word "basketball" in the title were isolated. No date, language, journal, or country of origin restrictions were placed on this search.

This search yielded 2,704 total articles, which were sorted in descending order based on the number of citations. The title and abstract of each article were then reviewed in order to determine its relevance to basketball. Only articles that had basketball as the focus of the study were included. For experimental studies, this was defined as articles that presented independent data for basketball players. If a study was unclear or if there were a question as to whether it should be excluded, the full article was obtained and reviewed by two independent authors to ultimately decide upon inclusion or exclusion. Duplicate studies were removed.

A total of 56 articles were reviewed in order to reach the 50 most cited studies that met the inclusion criteria. These 50 studies were reviewed by two authors to obtain the following information: author name, publication year, country of origin (determined by first author affiliation), journal name, category of research (original research, review article, case study, short communication/technical report, letter to the editors, point-counterpoint, editorial, or thesis), main research topic area (physiology, biomechanics, nutrition, training and testing, sports medicine, performance analysis, sport psychology, coaching, or social sciences), and the level of evidence for clinical articles based on the guidelines published by The Centre for EvidenceBased Medicine (CEBM) ${ }^{48}$ The level of evidence was determined by a consensus opinion between the second and third authors, both of which are medical students with research experience who were instructed on how to classify studies by the physicians on this study. If there was still a question of classification, the senior author, an experienced orthopedic surgeon specialized in sports medicine, was consulted. For articles classified as original research, the type of study (observational or experimental), gender of study participants (male, female, or both), competitive level of participants (elite, non-elite, or both), and the age group of participants (youth, adult, or all) were determined. An elite competitive level included participants who were classified as either semi-professional or professional athletes. Youth, high school, college, and recreational basketball players were classified as non-elite. If an article incorporated a systematic approach to reviewing the literature or if a meta-analysis were performed, the article was classified in the "review article" category. The citation density, which represents the number of citations per year since publication for each of the 50 studies, was also calculated and recorded.

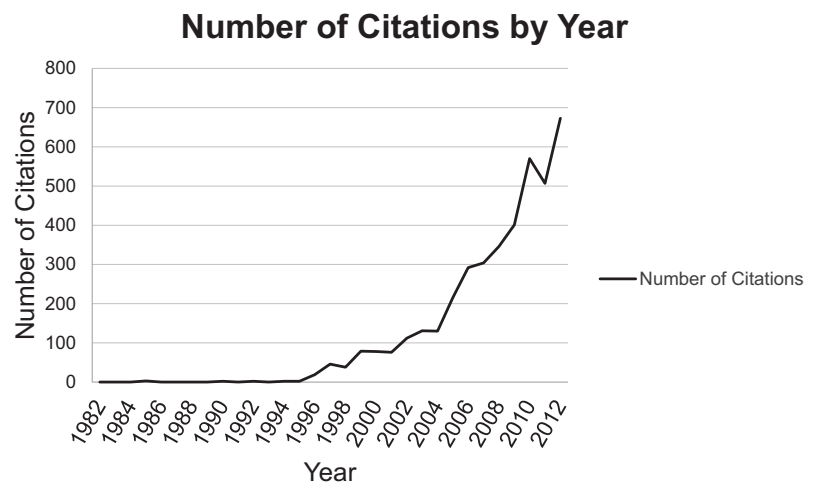

Fig 2. Number of citations by year. Total number of citations generated by the top 50 most cited basketball articles by year. 


\section{Number of Articles by Country of Origin}

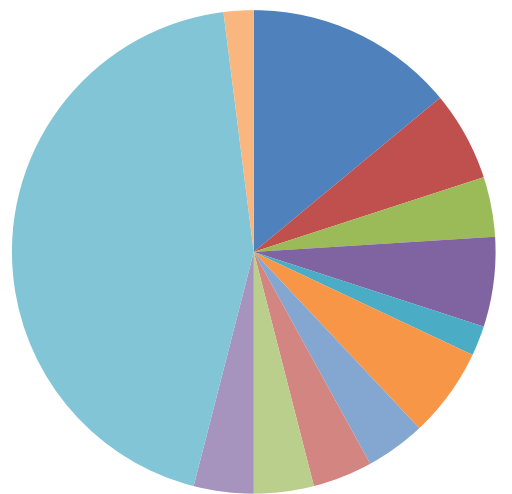

Australia

- Canada

- Finland

arance

- Israel

- Italy

Norway

Serbia

- Tunisia

UK

Fig 3. Number of articles by country of origin. Number of top 50 cited basked articles by the country of origin.

\section{Results}

Table 1 lists the 50 most cited articles in basketball research. The number of citations per article ranged from 1,017 to 116 . The average number of citations was 242.9, while the median was 164.5. The 50 most cited articles rank, article title, total citations, and citation density are listed in Table 1. Characteristics of these 50 articles are analyzed in Figs 1-4. The number of a articles published by year (Fig 1), the number of citations per year (Fig 2), country of origin (Fig 3), and level of evidence (Fig 4) are highlighted.

Of the 50 articles shown in Table 1, 37 articles were original research articles, 12 were review articles, and 1 was a short communication/technical document. Four authors published more than one article included in this list. Three of these authors published two articles (Agel, LaBella, and Abdelkrim), while one author published three (Montgomery). The number of articles published in each journal is listed in Table 2, while the top 20 most cited articles since 2013 are listed in Table 3.

Of the 37 original research articles in our study, 16 were experimental, while 21 were observational. In the original research articles, the investigators conducted their

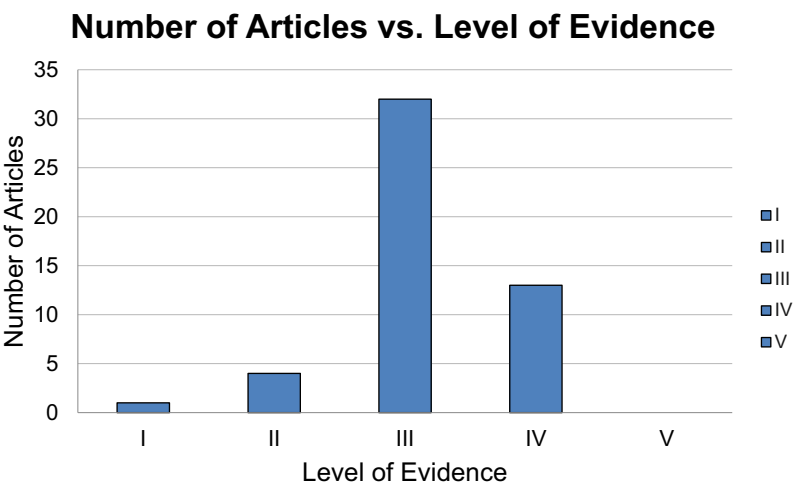

Fig 4. Number of articles versus level of evidence. The number of top 50 basketball articles by level of evidence. research with male participants (17), female participants (6), or a combination of both male and female participants (14). This research investigated both elite and non-elite competition levels, with non-elite settings being more common (22 to 15). The investigators also conducted these studies with youth and adult groups, with 24 of the studies involving adults and 13 involving youth.

The top 50 most cited articles in basketball covered a variety of different topics. The most common topic of research was sports medicine with 20 articles. The second most common area of research was physiology with 11 articles. Other topics included performance analysis (7), biomechanics (4), coaching (2), training and testing (2), sports psychology (2), and social sciences (2). Ten of the top 50 articles focused on kneerelated topics. These articles had an average citation density of 22.1. Of the articles with the 9 highest citation densities, 6 analyzed the knee. Anterior cruciate ligament injuries made up 6 of the 10 knee-related articles. Three articles examined ankle injuries and had an average citation density of 11.9. One article focused on oral injuries and had a citation density of 6.32. No publications exclusively investigated injuries of the upper extremities or trunk.

\section{Discussion}

The majority of the research articles included in the top 50 were focused on medicine-related topics. With such a heavy focus on medicine, sports medicine doctors and physicians who treat basketball players could benefit from a study of the articles in our analysis. When the

Table 2. The Top 50 Cited Basketball Journals of Origin

\begin{tabular}{lc}
\hline & Number of \\
Journal of Origin & Articles \\
\hline American Journal of Sports Medicine & 13 \\
Journal of Strength and Conditioning Research & 5 \\
Journal of Sports Sciences & 4 \\
Journal of Athletic Training & 3 \\
Scandinavian Journal of Medicine $\theta$ Science in Sports & 3 \\
Medicine and Science in Sports and Exercise & 2 \\
British Journal of Sports Medicine & 2 \\
Clinical Journal of Sports Medicine & 2 \\
International Journal of Sports Medicine & 2 \\
Sports Medicine & 2 \\
Archives of Pediatric $\theta$ Adolescent Medicine & 1 \\
British Medical Journal & 1 \\
International Journal of Sports Physiology & 1 \\
$\quad$ and Performance & \\
Journal of Orthopaedic $\theta$ Sports Physical Therapy & 1 \\
Journal of Science and Medicine in Sport & 1 \\
Journal of Sport $\theta$ Exercise Psychology & 1 \\
Journal of Sports Medicine and Physical Fitness & 1 \\
Nature Neuroscience & 1 \\
Operations Research & 1 \\
Sesearch Quarterly for Exercise and Sport & 1 \\
Journal of Applied Psychology & 1 \\
\hline & 1 \\
\hline
\end{tabular}


Table 3. The Top 20 Most Cited Basketball Articles Since 2013

Rank Article Title

Total Citations Citation Density

in young female basketball and floorball players. Am J Sports Med 2017;45:386-393. https://doi.org/

138

34.50

$10.1177 / 0363546516665810$.

2 Stojanović E, Stojiljković N, Scanlan AT, Dalbo VJ, Berkelmans DM, Milanović Z. The activity demands and physiological responses encountered during basketball match-play: A systematic review. Sports Med 2018;48:111-135. https://doi.org/10.1007/s40279-017-0794-z.

Spiteri T, Nimphius S, Hart NH, Specos C, Sheppard JM, Newton RU. Contribution of strength characteristics to change of direction and agility performance in female basketball athletes. $J$ Strength Cond Res 2014;28:2415-2423. https://doi.org/10.1519/JSC.0000000000000547.

Amin NH, Old AB, Tabb LP, Garg R, Toossi N, Cerynik DL. Performance outcomes after repair of complete Achilles tendon ruptures in National Basketball Association players. Am J Sports Med 2013;41:1864-1868. https://doi.org/10.1177/0363546513490659.

Siebenrock KA, Behning A, Mamisch TC, Schwab JM. Growth plate alteration precedes cam-type deformity in elite basketball players. Clin Orthop Relat Res 2013;471:1084-1091. https://doi.org/10. 1007/s1 1999-012-2740-6.

Torres-Unda J, Zarrazquin I, Gil J, et al. Anthropometric, physiological and maturational characteristics in selected elite and non-elite male adolescent basketball players. J Sports Sci 2013;31:196-203. https://doi.org/10.1080/02640414.2012.725133.

Spiteri T, Newton RU, Binetti M, Hart NH, Sheppard JM, Nimphius S. Mechanical determinants of faster change of direction and agility performance in female basketball athletes. $J$ Strength Cond Res 2015;29:2205-2214. https://doi.org/10.1519/JSC.0000000000000876.

Scanlan AT, Wen N, Tucker PS, Dalbo VJ. The relationships between internal and external training load models during basketball training. J Strength Cond Res 2014;28:2397-2405. https://doi.org/10.1519/ JSC.0000000000000458.

Sampaio J, McGarry T, Calleja-González J, Sáiz Schelling I Del Alcázar X, Balciunas M. Exploring game performance in the National Basketball Association using player tracking data. PLOS ONE 2015;10:e0132894. https://doi.org/10.1371/journal.pone.0132894.

Gómez MA, Lorenzo A, Ibañez SJ, Sampaio J. Ball possession effectiveness in men's and women's elite basketball according to situational variables in different game periods. J Sports Sci 2013;31:1578-1587. https://doi.org/10.1080/02640414.2013.792942.

11 Fox JL, Scanlan AT, Stanton R. A review of player monitoring approaches in basketball: Current trends and future directions. J Strength Cond Res 2017;31:2021-2029. https://doi.org/10.1519/JSC. 0000000000001964.

Conte D, Favero TG, Lupo C, Francioni FM, Capranica L, Tessitore A. Time-motion analysis of Italian elite women's basketball games: Individual and team analyses. J Strength Cond Res 2015;29:144-150. https://doi.org/10.1519/JSC.0000000000000633.

13 Torres-Ronda L, Ric A, Llabres-Torres I, de Las Heras B, Schelling I Del Alcazar X. Position-dependent cardiovascular response and time-motion analysis during training drills and friendly matches in elite male basketball players. J Strength Cond Res 2016;30:60-70. https://doi.org/10.1519/JSC. 0000000000001043.

14 Schelling X, Torres L. Accelerometer load profiles for basketball-specific drills in elite players. J Sports Sci Med 2016;15:585-591.

García J, Ibáñez SJ, De Santos RM, Leite N, Sampaio J. Identifying basketball performance indicators in regular season and playoff games. J Hum Kinet 2013;36:161-168. https://doi.org/10.2478/hukin2013-0016.

Puente C, Abián-Vicén J, Areces F, López R, Del Coso J. Physical and physiological demands of experienced male basketball players during a competitive game. J Strength Cond Res 2017;31:956-962. https://doi.org/10.1519/JSC.0000000000001577. Traditional vs. sport-specific vertical jump tests: Reliability, validity, and relationship with the legs strength and sprint performance in adult and teen soccer and basketball players. J Strength Cond Res 2017;31:196-206. https://doi.org/10.1519/JSC.0000000000001476.

18 Mangine GT, Hoffman JR, Wells AJ, et al. Visual tracking speed is related to basketball-specific measures of performance in NBA players. J Strength Cond Res 2014;28:2406-2414. https://doi.org/ 10. 1519/JSC.0000000000000550.

19 Fox JL, Stanton R, Scanlan AT. A comparison of training and competition demands in semiprofessional male basketball players. Res Q Exerc Sport 2018;89:103-111. https://doi.org/10.1080/02701367.2017. 1410693.

20 Klusemann MJ, Pyne DB, Hopkins WG, Drinkwater EJ. Activity profiles and demands of seasonal and tournament basketball competition. Int J Sports Physiol Perform 2013;8:623-629. https://doi.org/10. 1123 /ijspp.8.6.623. 
articles related to medicine were analyzed further, it became apparent that interest in knee-related injuries is high. Articles that examined injuries of other parts of the body, including ankle, mouth and shoulder injuries, were less prominent in our analysis. Knee injuries, particularly anterior cruciate ligament injuries, appear to be an area of high interest to current investigators.

Articles in our analysis originated from 13 different countries. Roughly half of all articles were published in the United States, and 35 were published in primarily English-speaking countries. The majority of other countries were European. In comparison, a soccer analysis from Brito et al. found that only $18 \%$ of the top 50 articles were published in the United States, while all other articles were published in Europe. ${ }^{35}$ These findings may indicate a deficiency in the number of research articles available or simply a lack of interest in research from areas with little to no highly cited publications, such as in Asia. These results may also be explained by basketball's popularity in a given country.

Finally, the publications included were chosen on the basis of citation numbers alone. This metric, although useful in identifying articles with high levels of influence and utility, is influenced by a variety of factors and should not be used as the sole determinate of article impact. Citation density, among other factors, may be useful to researchers as they seek to obtain the most current view of influential research. Individuals using our analysis should also understand that articles not included in our analysis can be very impactful in their clinical practice and future research, and these articles should be explored further.

\section{Limitations}

A limitation to our study, and to bibliometric analysis in general, is the exclusion of newer publications. Newer publications did not have the time to accrue citations and, thus, were excluded from the top 50 articles. However, our analysis did include citation density statistics, which control for the effect of publication year. Further, we have included a table listing the top 20 most-cited articles since 2012 to include these newer articles. Another potential limitation of our study is that we only used one database. The use of other databases may result in slightly different results than our findings; however the Web of Knowledge database is commonly used in bibliometric analyses. ${ }^{40-47}$

\section{Conclusion}

A majority of the top 50 research articles were from English-speaking countries, published after 2000, primarily focused on medicine-related topics, and were Level III evidence. Publications examining knee injuries were the most highly cited and appear to be of high interest to current investigators. The prestige of an author's name appeared to be less influential to the number of citations.

\section{References}

1. Cantwell JD. The physician who invented basketball. Am J Cardiol 2004;93:1075-1077. doi:10.1016/j.amjcard.2003. 12.068

2. International Basketball Migration Report 2019. FIBA basketball. http://www.fiba.basketball/documents/ ibmr2019.pdf. Accessed June 21, 2020.

3. 2018-19 High School Athletics Participation Survey. National Federation of State High School Associations. https://www.nfhs.org/media/1020412/2018-19_participa tion_survey.pdf. Accessed June 21, 2020.

4. DiFiori JP, Güllich A, Brenner JS, et al. The NBA and Youth Basketball: Recommendations for promoting a healthy and positive experience. Sports Med 2018;48: 2053-2065. doi:10.1007/s40279-018-0950-0.

5. National Health Statistics Reports, Number 133, November 15, 2019. 2019:15.

6. Rechel JA, Yard EE, Comstock RD. An epidemiologic comparison of high school sports injuries sustained in practice and competition. J Athl Train 2008;43:197-204. doi:10.4085/1062-6050-43.2.197.

7. Ben Abdelkrim N, El Fazaa S, El Ati J. Time-motion analysis and physiological data of elite under-19-year-old basketball players during competition. Br J Sports Med 2007;41:69-75. discussion 75. doi:10.1136/bjsm.2006.032318.

8. McInnes SE, Carlson JS, Jones CJ, McKenna MJ. The physiological load imposed on basketball players during competition. J Sports Sci 1995;13:387-397. doi:10.1080/ 02640419508732254.

9. Button C, MacLeod M, Sanders R, Coleman S. Examining movement variability in the basketball free-throw action at different skill levels. Res Q Exerc Sport 2003;74:257-269. doi:10.1080/02701367.2003.10609090.

10. Ford KR, Myer GD, Hewett TE. Valgus knee motion during landing in high school female and male basketball players. Med Sci Sports Exerc 2003;35:1745-1750. doi:10. 1249/01.MSS.0000089346.85744.D9.

11. Maffiuletti NA, Cometti G, Amiridis IG, Martin A, Pousson M, Chatard JC. The effects of electromyostimulation training and basketball practice on muscle strength and jumping ability. Int J Sports Med 2000;21: 437-443. doi:10.1055/s-2000-3837.

12. Mah CD, Mah KE, Kezirian EJ, Dement WC. The effects of sleep extension on the athletic performance of collegiate basketball players. Sleep 2011;34:943-950. doi:10.5665/ SLEEP. 1132.

13. Manzi V, D'Ottavio S, Impellizzeri FM, Chaouachi A, Chamari K, Castagna C. Profile of weekly training load in elite male professional basketball players. J Strength Cond Res 2010;24:1399-1406. doi:10.1519/JSC.0b013e3181d7552a.

14. Dirks KT. Trust in leadership and team performance: Evidence from NCAA basketball. J Appl Psychol 2000;85: 1004-1012. doi:10.1037/0021-9010.85.6.1004.

15. Zarić I, Kukić F, Jovićević N, et al. Body height of elite basketball players: Do taller basketball teams rank better at the FIBA World Cup? Int J Environ Res Public Health 2020;17. doi:10.3390/ijerph17093141.

16. Adams AB, Simonson D. Publications, citations, and impact factors of leading investigators in critical care medicine. Respir Care 2004;49:276-281. 
17. Aldawsari K, Alotaibi MT, Alsaleh K. Top 100 cited articles on lumbar spondylolisthesis: A bibliographic analysis. Global Spine J 2020;10:353-360. doi:10.1177/2192568219868194.

18. Azer SA, Azer S. Bibliometric analysis of the top-cited gastroenterology and hepatology articles. BMJ Open 2016;6. doi:10.1136/bmjopen-2015-009889.

19. Azer SA, Azer S. What can we learn from top-cited articles in inflammatory bowel disease? A bibliometric analysis and assessment of the level of evidence. BMJ Open 2018;8: e021233. doi:10.1136/bmjopen-2017-021233.

20. Berlinberg A, Bilal J, Riaz IB, Kurtzman DJB. The 100 topcited publications in psoriatic arthritis: A bibliometric analysis. Int J Dermatol 2019;58:1023-1034. doi:10.1111/ ijd.14261.

21. Foley KG, Powell A, Lewis WG, Roberts SA. The 100 most cited articles investigating the radiological staging of oesophageal and junctional cancer: A bibliometric analysis. Insights Imaging 2016;7:619-628. doi:10.1007/s13244-016-0505-6.

22. Jiang Y, Hu R, Zhu G. Top 100 cited articles on infection in orthopaedics. Medicine (Baltimore) 2019;98. doi:10.1097/ MD.0000000000014067.

23. Kazımoğlu H, Dokur M. The top 100 cited articles on urological emergencies: A bibliometric analysis. Turk $J$ Urol 2018;44:239-250. doi:10.5152/tud.2017.82609.

24. Lai P, Liu Y, Xue J, He P, Qiu Y. The 100 most-cited articles on aortic dissection. BMC Cardiovasc Disord 2017;17. doi:10.1186/s12872-016-0426-9.

25. Latif A, Kapoor V, Sipra QUAR, et al. Disease milestones through bibliometric analysis of the top 100 cited articles in Multiple Myeloma. Cureus 2018;10:e2438. doi:10.7759/ cureus.2438.

26. Liu B, Liu S, Alastra AJ, et al. The 100 most cited vs. most relevant articles in the Journal of Neurosurgery: A bibliometric analysis. Cureus 11(4). doi:10.7759/cureus.4498.

27. Wang SQ, Gao YQ, Zhang C, Xie YJ, Wang JX, Xu FY. A bibliometric analysis using CiteSpace of publications from 1999 to 2018 on patient rehabilitation after total knee arthroplasty. Med Sci Monit 2020;26:e9207951-e920795-14. doi:10.12659/MSM.920795.

28. Moore ML, Pollock JR, McQuivey KS, Bingham JS. The top 50 most-cited shoulder arthroscopy studies. Arthrosc Sports Med Rehabil 2021;3:e277-e287. doi:10.1016/j.asmr. 2020.09.011.

29. McQuivey KS, Moore ML, Pollock JR, Hassebrock JD, Patel KA, Chhabra A. Top-100 most-cited sports-related concussion articles focus on symptomatology, epidemiology, and demographics. ASMAR 2021;3:el585-el597. doi:10.1016/j.asmr.2021.06.016.

30. Murphy SN, Moore ML, Pollock JR, McQuivey KS, Bingham JS. The top 50 most-cited knee arthroscopy studies. Arthrosc Sports Med Rehabil 2021;3:e1243-e1253. doi:10.1016/j.asmr.2021.05.006.

31. Zhang X, Estoque RC, Xie H, Murayama Y, Ranagalage M. Bibliometric analysis of highly cited articles on ecosystem services. PLoS One 2019;14. doi:10.1371/journal.pone. 0210707.

32. Eshraghi A, Osman NAA, Gholizadeh H, Ali S, Shadgan B. 100 top-cited scientific papers in limb prosthetics. Biomed Eng Online 2013;12:119. doi:10.1186/1475-925X-12-119.
33. Mishra L, Kim HC, Singh NR, Rath PP. The top 10 mostcited articles on the management of fractured instruments: a bibliometric analysis. Restor Dent Endod 2018;44. doi:10.5395/rde.2019.44.e2.

34. Azer SA. The top-cited articles in medical education: A bibliometric analysis. Acad Med 2015;90:1147-1161. doi: 10.1097/ACM.0000000000000780.

35. Brito J, Nassis GP, Seabra AT, Figueiredo P. Top 50 mostcited articles in medicine and science in football. BMJ Open Sport Exerc Med 2018;4. doi:10.1136/bmjsem-2018000388.

36. Andrade A, Dominski FH, Coimbra DR. Scientific production on indoor air quality of environments used for physical exercise and sports practice: Bibliometric analysis. J Environ Manage 2017;196:188-200. doi:10.1016/j. jenvman.2017.03.001.

37. Du L, Luo S, Liu G, Wang H, Zheng L, Zhang Y. The 100 top-cited studies about pain and depression. Front Psychol 2020;10. doi:10.3389/fpsyg.2019.03072.

38. Mahabee-Gittens EM, Gordon JS, Melink KF, Merianos AL. Top 100 cited articles in recent tobacco research. J Behav Health 2017;6:16-25. doi:10.5455/jbh. 20160814123529.

39. Yi F, Ma J, Ni W, et al. The top cited articles on glioma stem cells in Web of Science. Neural Regen Res 2013;8: 1431-1438. doi:10.3969/j.issn.1673-5374.2013.15.011.

40. Ahmad SS, Evangelopoulos DS, Abbasian M, Röder C, Kohl S. The hundred most-cited publications in orthopaedic knee research. J Bone Joint Surg Am 2014;96:e190. doi:10.2106/JBJS.N.00029.

41. Baldwin KD, Kovatch K, Namdari S, Sankar W, Flynn JM, Dormans JP. The 50 most cited articles in pediatric orthopedic surgery. J Pediatr Orthop B 2012;21:463-468. doi: 10.1097/BPB.0b013e328354b0cf.

42. Barbera J, Selverian S, Courington R, Mikhail C, Colvin A. The top 50 most influential articles in hip arthroscopy. Arthroscopy 2020;36:716-722. doi:10.1016/j.arthro.2019.09. 031.

43. Cassar Gheiti AJ, Downey RE, Byrne DP, Molony DC, Mulhall KJ. The 25 most cited articles in arthroscopic orthopaedic surgery. Arthroscopy 2012;28:548-564. doi:10. 1016/j.arthro.2011.08.312.

44. Holzer LA, Holzer G. The 50 highest cited papers in hip and knee arthroplasty. J Arthroplasty 2014;29:1878. doi: 10.1016/j.arth.2014.03.017.

45. Lefaivre KA, Shadgan B, O'Brien PJ. 100 most cited articles in orthopaedic surgery. Clin Orthop Relat Res 2011;469:1487-1497. doi:10.1007/s1 1999-010-1604-1.

46. Namdari S, Baldwin K, Kovatch K, Huffman GR, Glaser D. Fifty most cited articles in orthopedic shoulder surgery. J Shoulder Elbow Surg 2012;21:1796-1802. doi:10.1016/j.jse. 2011.11 .040$.

47. To P, Atkinson CT, Lee DH, Pappas ND. The most cited articles in hand surgery over the past 20-plus years: a modern-day reading list. J Hand Surg Am 2013;38: 983-987. doi:10.1016/j.jhsa.2013.02.004.

48. OCEBM Levels of Evidence. CEBM. Published May 1, 2016. https://www.cebm.net/2016/05/ocebm-levels-ofevidence/. Accessed June 17, 2020. 